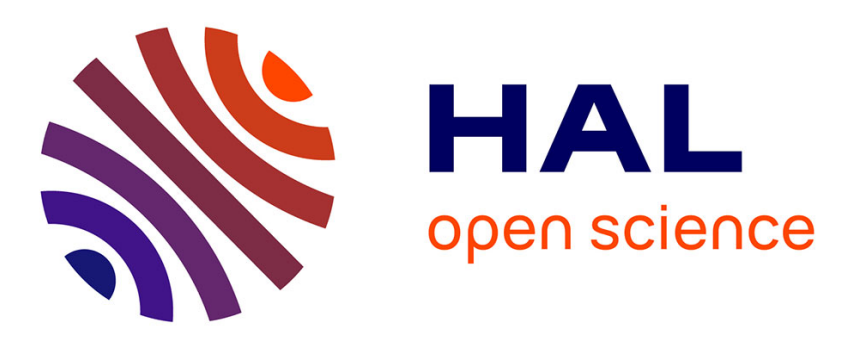

\title{
Encapsulant polymer blend films for bifacial heterojunction photovoltaic modules: Formulation, characterization and durability
}

Marilena Baiamonte, Sandrine Therias, Jean-Luc Gardette, Claudio Colletti, Nadka Tz Dintcheva

\section{To cite this version:}

Marilena Baiamonte, Sandrine Therias, Jean-Luc Gardette, Claudio Colletti, Nadka Tz Dintcheva. Encapsulant polymer blend films for bifacial heterojunction photovoltaic modules: Formulation, characterization and durability. Polymer Degradation and Stability, 2021, 193, pp.109716. 10.1016/j.polymdegradstab.2021.109716 . hal-03401790

\author{
HAL Id: hal-03401790 \\ https://hal.uca.fr/hal-03401790
}

Submitted on 25 Oct 2021

HAL is a multi-disciplinary open access archive for the deposit and dissemination of scientific research documents, whether they are published or not. The documents may come from teaching and research institutions in France or abroad, or from public or private research centers.
L'archive ouverte pluridisciplinaire HAL, est destinée au dépôt et à la diffusion de documents scientifiques de niveau recherche, publiés ou non, émanant des établissements d'enseignement et de recherche français ou étrangers, des laboratoires publics ou privés. 


\title{
Encapsulant polymer blend films for bifacial heterojunction photovoltaic modules: Formulation, characterization and durability
}

\author{
Marilena Baiamonte ${ }^{1}$, Sandrine Therias ${ }^{2}$, Jean-Luc Gardette ${ }^{2}$, \\ Claudio Colletti ${ }^{3}$, Nadka Tz. Dintcheva ${ }^{1^{\star}}$
}

${ }^{1}$ Dipartimento di Ingegneria, Università di Palermo, Viale delle Scienze, Ed. 6, 90128 Palermo, Italy

${ }^{2}$ Université Clermont Auvergne - CNRS - Clermont Auvergne INP, ICCF

F-63000 Clermont-Ferrand, France

${ }^{3}$ Enel Green Power SpA Contrada Blocco Torrazze - 95121 zona industriale Catania, Italy

\begin{abstract}
In this work, polymer blends based on ethylene vinyl acetate (EVA) and polyolefin (PO) at different weight ratios, also in the presence of a crosslinking agent (CA) and stabilizers (STAB), were investigated as potential encapsulants for PV modules. The EVA/PO blends were processed by melt mixing and then subjected to compression moulding following industrial lamination processing conditions. The EVA/PO films were characterized by mechanical tensile tests and thermogravimetric analysis, and the obtained results highlight the beneficial effect of PO at low amounts on the mechanical behaviour and thermal resistance at high temperatures $\left(>300{ }^{\circ} \mathrm{C}\right)$. All EVA/PO films were subjected to UVB exposure, and the photoaging extent was monitored by FTIR and UV-visible spectroscopies. Therefore, EVA-rich blends can be considered as good candidates for PV module encapsulants, given a compromise in the behaviour before and after photoaging.
\end{abstract}

Keywords: PV module encapsulant; EVA-based blends; crosslinking agent; stabilizing system

\section{Introduction}

" Corresponding author. Tel: +39 09123863704. E-mail address: nadka.dintcheva@ unipa.it (N.Tz. Dintcheva). 
Everyday, our energy demand is greater because of the Earth's population increase, and as calculated, it is expected to double during the next two decades, reaching approximately 778 exajoules (EJ) by 2035. [1] Energy recovery by combustion of traditional fossil fuel sources, such as coal, crude oil and natural gas, produces carbon dioxide and pollutants, which have negative environmental and health impacts. The recovery of energy, which is inherent in natural phenomena, such as sunlight, winds and tides, is extremely attractive, and numerous current searches and pilot industrial productions demonstrate its feasibility and advantages. Therefore, given its opportunity to produce energy without emissions or pollutants, energy recovery using solar photovoltaic (PV) devices is being unceasingly developed.

According to the current statement by 3SUN (ENEL Green Power, Italy), the efficiency for energy recovery can be significantly increased using a novel, highly reliable bifacial heterojunction PV module (see Figure 1a-b). This innovative PV module offers the possibility to recover energy using both external surfaces, as shown in Figure 1a-b. The cells of the bifacial PV module are based on heterojunction technology that combines two different amorphous and crystalline silicons. The heterojunction PV module is more efficient and durable than the traditional one-face PV module because of its ability to efficiently capture and recover solar radiation, and extension of its life cycle from 25 to 35-40 years, showing high performance even under extreme climatic conditions. [2]

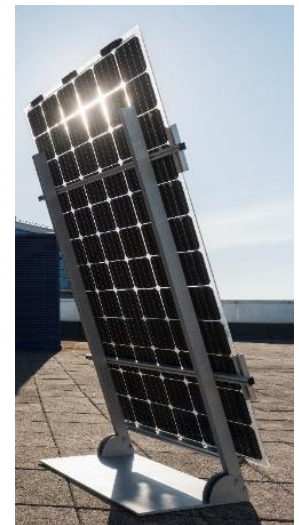

(a)

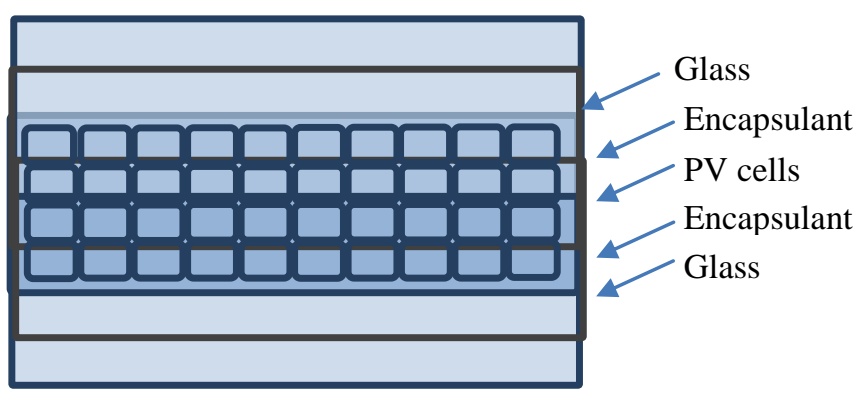

(b)

Figure 1 Novel, highly reliable bifacial heterojunction glass/glass PV module: (a) image and (b) schematic structure representation (by 3SUN - ENEL Green Power, Italy)

However, PV devices must be produced using materials with appropriate weatherability and durability, and for efficient energy recovery, PV modules must maintain unchanged material properties and performance during service. The polymer materials in PV modules are used to produce backsheets for one-sided PV modules and encapsulants located between the PV cells and glass sheets, with a special task in protection against atmospheric agents. [3-4] 
The encapsulant polymer materials must ensure and maintain optical transparency in the solar spectrum, i.e., between 380 and $1200 \mathrm{~nm}$, and provide coupling between the solar cells and glass sheets, ensuring suitable protection from detrimental environmental elements. Overall, polymerbased encapsulants must have (i) high barrier properties against water and oxygen; (ii) optical transparency; (iii) easy processability and flexibility; (iv) electrical and physical isolation; and (iv) good adhesion with PV cells and glass sheets, avoiding delamination and humidity penetration. [58]

The first-generation encapsulants for PV modules were based on polydimethylsiloxane (PDMS) because of its excellent thermal and UV stability. Due to high production costs, PDMS has been replaced by cheaper and similar performing materials, such as ethylene vinyl acetate (EVA), polyvinyl butyral (PVB), and thermoplastic polyolefins (TPOs). Unfortunately, the adhesion between EVA, PVB, TPO encapsulants and PV components must be improved using suitable adhesion promoters/primers, such as trialkoxy silane. [9] According to the literature, interface encapsulation/glass is stronger than encapsulation/cell [10-12], and for both interfaces, the use of adhesion promoters/primers is required to facilitate and ensure correct PV assembly. [13-15] Unfortunately, the adhesion promoters/primers could degrade during PV module lamination and assembly, developing low molecular weight gas, which could cause delamination and often precede corrosion in fielded PV modules. [13, 16-17] Interestingly, TPO-encapsulated films are more durable than EVA films because their yellowing upon UV irradiation is less pronounced, but TPO films require a large use of adhesion promoters/primers. [18]

Today, the most common encapsulant material for PV devices is EVA copolymers because of its good compromise between cost and performance, e.g., excellent optical properties, impermeability towards water and gas and good mechanical properties. However, due to exposure to atmospheric agents, particularly UV irradiation and humidity, EVA degrades by a chain scission mechanism that produces acetic acid, which lowers the $\mathrm{pH}$ and increases the speed of surface corrosion. [19] Unfortunately, according to the literature, the byproducts of low molecular weights, coming from both EVA degradation and/or degradation of adhesion promoters/primers, could induce incorrect PV module assembly and further delamination, which negatively affect the energy recovery efficiency of the devices in service. [20-21] The lowering efficiency of the photovoltaic cells due to all these factors is reported by electroluminescence analysis carried out on the modules to check the operating status of the cells. [18, 22-25]. Therefore, in the past, the degradation pathway of EVA has been accurately studied and documented [26-30] under extreme conditions, such as damp-heat and hot air ageing [31-32], and currently, due to interest in using this material as 
PV encapsulants, the degradation pathway is confirmed accurately by innovative luminescent spectroscopic techniques [33-34] and accurate infrared spectroscopy analysis. [35]

However, the durability and weatherability of EVA films/sheets can be significantly improved by adding appropriate additives, such as antioxidants, UV absorbers and crosslinking agents. [3637] Unfortunately, some of these additives can induce untimely EVA yellowing and opacification, negatively affecting the use of this polymer as a PV encapsulant. [38-40]

In addition, currently published papers by Deng et al. [41] report a failure risk of PV modules due to a significant local hot spot temperature increase [42-43]. Specifically, the simulated and measured temperature values are between $150{ }^{\circ} \mathrm{C}$ and $170{ }^{\circ} \mathrm{C}$ for the undamaged 60 - and 72 -cell PV modules, respectively. In addition, the authors demonstrated that the hot spot temperatures for defect type $1 \times 1 \mathrm{~mm}^{2}$ cells can reach ca. $294^{\circ} \mathrm{C}$ on the cells surface and ca. $211^{\circ} \mathrm{C}$ on the backsheet surface. Surprisingly, the hot spot temperature can rise up to ca. $350{ }^{\circ} \mathrm{C}$ for $10 \times 10 \mathrm{~mm}^{2}$ cells defect area. Therefore, the encapsulant films next to both cells and the backsheet are subjected to occasional hot spot temperature increases, and EVA degradation and deacetylation are favoured under these extreme thermal conditions.

In this work, potential encapsulants for PV modules based on blends of ethylene vinyl acetate (EVA) and polyolefin (PO), linear low-density polyethylene, at different weight ratios, were formulated and investigated, considering partial EVA replacement by thermoplastic olefin-based polymers. The introduction of PO in EVA blends aims to slow EVA degradation and yellowing, reduce acetic acid formation while keeping the VA units separated, and increase the thermal resistance to temperatures above $300{ }^{\circ} \mathrm{C}$. EVA/PO blends were combined with appropriate crosslinker, such as peroxide agent; and stabilizing systems, such as UV absorbers, antioxidants and metal deactivators. Their performance was compared to that of blends without additives. Therefore, EVA/PO blends, with and without crosslinking agent (CA) and stabilizers (STAB), were prepared by melt mixing in a mini-extruder, and then, the blends were subjected to prolonged thermal treatments under pressure to induce conditions similar to those experienced by PV modules during industrial lamination and assembly. The EVA/PO films with and without CA and STAB were characterized by tensile tests and thermogravimetric analysis. In addition, to evaluate the photooxidative resistance and durability, the EVA/PO blends were subjected to accelerated UVB exposure, and the progress of the degradation was monitored over time by accurate spectroscopic analysis. 


\section{Experimental section}

\subsection{Materials}

Both commercial polyethylene vinyl acetate (EVA) and linear low-density polyethylene (LLDPE) were used to formulate blends with compositions EVA/PO = 100/0, 75/25, 50/50, 25/75, and $0 / 100 \mathrm{wt} / \mathrm{wt} \%$.

Polyethylene vinyl acetate, named EVA, is a commercial copolymer Greenflex ${ }^{\circledR}$ (EVA28, Versalis spa - ex Polimeri Europa) with the following physical characteristics: vinyl acetate 28\%; density $=0.550 \mathrm{~g} / \mathrm{cm}^{3} ; \mathrm{MFR}\left(190{ }^{\circ} \mathrm{C} / 2.16 \mathrm{~kg}\right)=25 \mathrm{~g} / 10 \mathrm{~min} ; \mathrm{Tm}=75^{\circ} \mathrm{C}$.

Linear low-density polyethylene, named PO, is a commercial Ziegler-Natta polyolefin Clearflex ${ }^{\circledR}$ (LLDPE, FG106, Versalis spa - ex. Polimeri Europa) with physical characteristics: density $=0.918 \mathrm{~g} / \mathrm{cm}^{3} ; \operatorname{MFR}\left(190{ }^{\circ} \mathrm{C} / 2.16 \mathrm{~kg}\right)=1 \mathrm{~g} / 10 \mathrm{~min} ; \mathrm{Tm}=125^{\circ} \mathrm{C}$.

Crosslinking agent (CA) and stabilizing systems (STAB) in different percentages were also used, as follows:

(i) Crosslinking agent (CA), 2,5-bis(tert-butylperoxy)-2,5-dimethylhexane, named Luperox® 101 (LUP); Luperox was purchased from Sigma-Aldrich. LUP was added at 1.5 wt.\% during processing.

(ii) An ultraviolet light absorber ( $U V$ abs), methanone, [2-hydroxy-4-(octyloxy)phenyl]phenyl, named Chimassorb® 81, was supplied by Ciba Specialty Chemicals. UVabs was added at 1 wt.\% during processing.

(iii) Metal deactivator and antioxidant (MD), 2',3-bis[[3-[3,5-di-tert.-butyl-4hydroxyphenyl]propionyl]] propionohydrazide, named Irganox ${ }^{\circledR}$ MD1024, was supplied by Ciba Specialty Chemicals. MD was added at $0.5 \mathrm{wt} . \%$ during processing.

(iv) Primary phenolic antioxidant (AO), octadecyl 3-(3,5-di-tert-butyl-4-hydroxyphenyl) propionate, named Irganox ${ }^{\circledR}$ 1076, was supplied by Ciba Specialty Chemicals. AO was added at 0.5 wt.\% during processing.

\subsection{Blend processing and thermal treatment}

EVA/PO samples, with and without additives (i.e., crosslinking agent or crosslinking agent/stabilizers), were processed in a mini-extruder Thermo Haake Minilab at $150{ }^{\circ} \mathrm{C}$ for 5 min at $50 \mathrm{rpm}$. The crosslinking agent (Luperox) was added to the matrices after $4 \mathrm{~min}$ of processing and mixed for $1 \mathrm{~min}$. All stabilizers, i.e., UVabs, MD and AO were added to the matrices after 3 minutes of processing and mixed for 2 minutes. Then, the samples were processed in a Carver press at $150{ }^{\circ} \mathrm{C}$ for $5 \mathrm{~min}$ ( $1 \mathrm{~min}$ preheating and $4 \mathrm{~min}$ pressing) to simulate the thermal treatment of PV 
module lamination/assembly conditions. Films with a thickness (D) of approximately $94 \mu \mathrm{m}$ were prepared for UVB exposure and spectroscopic characterizations.

\subsection{Characterizations}

- Accelerated photoageing

UV-visible light irradiation $(\lambda>300 \mathrm{~nm})$ of films was performed in a SEPAP 12/24 unit, which was designed for studying polymer photodegradation during artificial ageing with mediumaccelerated conditions [44]. The chamber consisted of a square reactor equipped with four mediumpressure mercury lamps situated vertically at each corner of the chamber. Wavelengths below 300 $\mathrm{nm}$ were filtered by the borosilicate envelope of the lamps, acting as a UV filter below $300 \mathrm{~nm}$. The delivered light intensity was $90 \mathrm{~W} \cdot \mathrm{m}^{-2}$ in the wavelength range of $300-420 \mathrm{~nm}$, and the chamber temperature was measured at $52{ }^{\circ} \mathrm{C}$.

- FTIR Spectroscopy: The spectra were recorded with a Nicolet 6700 FTIR spectrometer working with OMNIC software. The spectra were obtained using 32 scans and a $4 \mathrm{~cm}^{-1}$ resolution.

- A $U V$-visible spectrometer (UVvis-2600 SHIMADZU) was used to record UV-Vis spectra by performing 8 scans between 200 and $1100 \mathrm{~nm}$ at a resolution of $1 \mathrm{~nm}$. The values of the linear attenuation coefficient $(\mathrm{k})$ were calculated considering the measured absorption values (A) and sample thickness (D) using the formula $\mathrm{k}=\mathrm{A} /(2.3 \mathrm{D})$.

- Tensile tests were carried out using a universal testing machine (Instron model 3365, UK), following the ASTM D882 method, on rectangular samples cut from the films. The tests were performed using a tensile speed of $1 \mathrm{~mm} / \mathrm{min}$ for 1 minute to evaluate the Young's modulus, and then the velocity was increased to $10 \mathrm{~mm} / \mathrm{min}$ until sample breakage.

\section{- Thermogravimetric analysis}

Thermogravimetric analysis (TGA) was carried out using an Exstar TG/DTA Seiko 7200 instrument with a heating rate of $10{ }^{\circ} \mathrm{C} / \mathrm{min}$ from 30 to $600{ }^{\circ} \mathrm{C}$ under nitrogen flow. The reported results are the average of three independent measurements on the samples (approximately $5 \mathrm{mg}$ ). The standard deviation was approximately $0.4 \%$ for each investigated sample. 


\section{Results and Discussion}

\subsection{Characterization of EVA/PO blends before ageing}

To investigate the mechanical behaviour of EVA/PO blends with and without crosslinking agents and stabilizers, thin films were prepared by compression moulding and subjected to tensile testing. In Figure 1a-c, the trends of elastic modulus (E), tensile strength (TS) and elongation at break (EB) as a function of the EVA/PO blend composition are shown. It is worth noting that the values of the elastic modulus increased significantly with PO addition, and the PO-rich blends showed a higher overall system rigidity than the EVA-rich blends (see Figure 1a). Due to the addition of a crosslinking agent, the elastic modulus values of EVA-rich blends were slightly higher, while those of PO-rich blends were slightly lower, in comparison to the elastic modulus values of EVA/PO blends without additives. Similar considerations can also be made for the E trends of EVA/PO blends containing both crosslinking agents and stabilizers. Therefore, the values of tensile strength of EVA- and PO-rich blends, with and without additives, were very similar and remained almost unchanged with blend composition (see Figure 1b). Similar observations were also seen for the trends of the elongation at break of all investigated EVA/PO blends (see Figure 1c). Therefore, the slight decreases of the properties at break, due to the presence of $\mathrm{CA}$ and $\mathrm{CA}+\mathrm{STAB}$, can be understood by considering that the system heterogeneity increases and the CA radicals are more efficient for EVA crosslinking, rather than PO, at chosen processing conditions. To improve the environmental resistance of the encapsulant films for PV modules, the films must imperatively contain both crosslinking agents and stabilizing systems, and for this specific application, high values of the properties at break are not required. Therefore, the observed decreases in the TS and $\mathrm{EB}$ values of EVA/PO+CA+STAB blends, which are $10 \%$ lower than the values of the EVA/PO blend, do not compromise the use of EVA-rich films as PV encapsulants. In summary, the EVA/PO $=75 / 25 \mathrm{wt} / \mathrm{wt} \%$ blend, with and without $\mathrm{CA}$ and STAB, showed a mechanical behaviour very similar to that of neat EVA, with and without CA and STAB, and it can thus be considered a good candidate for PV encapsulant applications.

To evaluate the effect of the EVA/PO blend composition on the thermal resistance, thermogravimetric analysis in an inert atmosphere of EVA/PO+CA+STAB was carried out, and the obtained thermograms are shown in Figure 2. EVA+CA+STAB was stable up to $290{ }^{\circ} \mathrm{C}$, and then weight loss began due to EVA deacetylation at high temperatures (> $400{ }^{\circ} \mathrm{C}$ ) from polymer decomposition. The weight losses of EVA+CA+STAB were ca. $2 \%$ at $300{ }^{\circ} \mathrm{C}$, ca. $17 \%$ at $350{ }^{\circ} \mathrm{C}$ and ca. $23 \%$ at $400{ }^{\circ} \mathrm{C}$, suggesting a reduced thermal resistance of this material in this temperature interval. $\mathrm{PO}+\mathrm{CA}+\mathrm{STAB}$ is more stable in the temperature range between 300 and $400{ }^{\circ} \mathrm{C}$, and its 
weight loss results ca. $8 \%$ at $400{ }^{\circ} \mathrm{C}$. Therefore, it is evident that the EVA/PO+CA+STAB blends showed slightly improved thermal stability at temperatures between 300 and $400{ }^{\circ} \mathrm{C}$ in comparison to $\mathrm{EVA}+\mathrm{CA}+\mathrm{STAB}$, suggesting a beneficial effect due to the presence of PO. Considering that the PV modules in service conditions could be subjected to occasional hot-spot temperature increases, the improved thermal resistance of EVA/PO blends at high temperatures, i.e., between $300-400{ }^{\circ} \mathrm{C}$, make these blends good candidates for PV encapsulants.

\subsection{Photoaging of EVA/PO blends}

To investigate the photooxidative resistance of EVA/PO blends with and without crosslinking agent and stabilizers, thin films (thickness ca. $94 \mu \mathrm{m}$ ) were subjected to accelerated artificial UVB ageing, and the degradation extent was monitored by infrared analysis.

Figure 3 shows the spectra of a selection of EVA/PO blend films with different ratios of EVA vs. PO, with and without CA and STAB, before and after $400 \mathrm{~h}$ of exposure to UV light.

The spectrum of EVA/PO 100/0 (Fig. 3a) is that of EVA, characterized by the typical absorption bands attributed to ester groups of EVA at 1734, 1234, 1018, and $607 \mathrm{~cm}^{-1}$. The spectra of EVA/PO with increasing amounts of polyethylene (Fig. 3c, d) showed a progressive decrease in the EVA absorption bands, which were not observed in the case of the EVA/PO $=0 / 100$ sample (Fig. 3b). Processing the samples with the crosslinking agent produced a weak absorption band at $1720 \mathrm{~cm}^{-1}$, as observed in the spectrum of the EVA/PO $=0 / 100$ sample (Fig. 3b). This likely reflects a slight oxidation of the polymeric matrix induced by processing in the presence of the crosslinking agent. This band cannot be observed in the spectra of the samples containing EVA since the broad EVA band at $1734 \mathrm{~cm}^{-1}$ prevents the observation of any weak absorption band at the same frequency. The introduction of the stabilizing system gave a few supplementary absorption bands. One can be observed at $1740 \mathrm{~cm}^{-1}$, but only in the case of the EVA/PO 0/100 sample (Fig. $3 b)$, for the reasons explained above. This absorption maximum is attributable to $\operatorname{Irganox}{ }^{\circledR} 1076$. A broad band was also observed between 1650 and $1550 \mathrm{~cm}^{-1}$, with several maxima at 1610, 1595 and $1580 \mathrm{~cm}^{-1}$ for the main maxima (Fig. $3 \mathrm{~b}$ and e). This broad band was observed for all the samples containing the stabilizing system.

Exposing the samples to irradiation in the presence of atmospheric oxygen provoked dramatic modifications of the infrared spectra. The main modifications occurred in the domain 1900-1500 $\mathrm{cm}^{-1}$ and reflect the oxidation of the polymeric matrix. In the case of the EVA/PO =0/100 sample (Fig. 3b), one observes the well-known oxidation bands of polyethylene reported many times in the literature (see, for example, [45]). According to the literature, PO photodegradation proceeds overall with the formation of new bands in the carbonyl range $1700-1800 \mathrm{~cm}^{-1}$, as follows: at 1715 
$\mathrm{cm}^{-1}$, due to carboxylic acid vibrations; at $1725 \mathrm{~cm}^{-1}$, due to carbonyl (aldehyde and ketone) stretching vibrations; at $1738 \mathrm{~cm}^{-1}$, due to ester stretching vibrations; and at $1780 \mathrm{~cm}^{-1}$, due to $\gamma$ lactone vibrations; a new band at $1645 \mathrm{~cm}^{-1}$, due to vinyl alkene vibrations; and new bands in the hydroxyl range $3200-3600 \mathrm{~cm}^{-1}$, due to hydroxyl group vibrations. [48]

In the case of the samples containing EVA (Figs. 3a, c-e), broadening of the acetate band at $1740 \mathrm{~cm}^{-1}$ can be noticed. In the carbonyl domain $\left(1900-1500 \mathrm{~cm}^{-1}\right)$, the subtracted spectra reveal the formation of carboxylic acid and lactone at 1718 and $1780 \mathrm{~cm}^{-1}$, respectively [46-47]. The photooxidation mechanism of EVA can be considered fairly well understood [30]. Hydrogen abstraction on the polymeric backbone either on a methylene group (in PE sequences) or on a tertiary carbon atom in the $\alpha$-position of the acetate produces macroradicals. These radicals react with oxygen, leading to a peroxy radical that gives a hydroperoxide by abstraction of a labile hydrogen atom. The alkoxy radical formed on PE sequences leads to the formation of alcohol or ketone. The oxidation of the tertiary carbon atoms leads only to the formation of ketones, and no alcohols are obtained from this route. Both routes of oxidation lead to similar chain ketones. Photolysis of the ketones by Norrish I and Norrish II reactions produces various species that give rise to carboxylic acids or lactones and to vinyl unsaturated groups (from Norrish II reactions).

Taking into account these considerations, to compare the photoaging behaviour of blends of $\mathrm{EVA} / \mathrm{PO}=100 / 0,75 / 25,50 / 50,25 / 75$ and 0/100 wt/wt $\%$, with or without CA and Stab, we chose to follow the changes in absorbance at $1780 \mathrm{~cm}^{-1}$ due to lactone carbonyl vibrations.

Figures $4 \mathrm{a}$ and $4 \mathrm{~b}$ show the variations in absorbance at $1780 \mathrm{~cm}^{-1}$ calculated as the difference in the absorbance after light exposure for $200 \mathrm{~h}$ and $400 \mathrm{~h}$, respectively, and the absorbance before exposure $(0 \mathrm{~h})$. The data concerning all the samples studied here are presented.

Several comments should be noted concerning these figures:

- Regarding the non-crosslinked samples (curve a), the results indicate that polyethylene $(\mathrm{EVA} / \mathrm{PO}=0 / 100)$ is more sensitive to photooxidation than EVA $(\mathrm{EVA} / \mathrm{PO}=100 / 0)$. The most noticeable result involves the samples with various amounts of EVA vs. PO: it is indeed observed that the absorbance at $1780 \mathrm{~cm}^{-1}$ varies linearly with the respective amount of EVA and PO. This suggests that there is no interaction of one polymer on the other, as far as photooxidation is concerned. This is not a general rule, and it has been reported that in the case of polyethylenepolyamide blends with different compositions, the rates of photooxidation for all blends were higher than the rates corresponding to the two homopolymers [49].

- In the case of the crosslinked samples (curve b), the results indicate that there is no effect of crosslinking on the rate of oxidation of EVA, whereas one observes that crosslinking results in a slight degrading effect on the samples containing polyethylene. One also observes linear variations 
of the absorbance with the respective amount of EVA and PO. The degradation effect could result from the weak oxidation of PO due to processing in the presence of the crosslinking agent. Oxidation of EVA due to processing cannot be observed because of the presence of the broad EVA band at $1734 \mathrm{~cm}^{-1}$. Our results suggest that EVA is less sensitive to oxidation resulting from processing in the presence of a crosslinking agent.

- In the case of those samples crosslinked and stabilized (curve c), the variations with the relative amount of EVA and PO are different. In the case of EVA (EVA/PO = 100/0), a stabilizing effect of the stabilizer was observed, approximately a factor of 1.9. A weaker factor of approximately 1.6 was observed in the case of the sample EVA/PO $=75 / 25$. However, when the amount of PO increased (samples EVA/PO $=75 / 25$ to $0 / 100$ ), the stabilizing effect increased much more, and the differences with curve $b$ increase with the amount of polyethylene, reaching a value of approximately 5.6 for the stabilizing effect in the case of polyethylene. In this case, there was no linear variation opposite to that reported above. The stabilizer was much more efficient in stabilizing polyethylene than EVA.

These results indicate that crosslinking has no influence on the photostability of EVA but has a slight prodegrading effect in the case of blends with polyethylene. It is worth noting that the stabilizer system can protect the various blends but is much more efficient in the case of polyethylene than in the case of EVA.

To investigate the optical performance of EVA/PO blend films, UV-visible spectroscopy analysis was performed, and the obtained spectra before $(0 \mathrm{~h})$ and after UVB exposure $(400 \mathrm{~h})$ are plotted in Figure 5. Interestingly, in the UV-vis spectra of EVA/PO films containing both crosslinking agent and stabilizers, a beneficial effect was noticed due to the presence of the stabilizers. As expected, the EVA/PO+CA+STAB films showed pronounced absorbance in the UV range, which can be attributed to the protective activity of added stabilizers, specifically UV absorbers.

Therefore, to evaluate the EVA/PO film transparency, the values of the linear attenuation coefficient (k) were calculated considering the measured absorption values (A) and sample thickness (D) using the formula reported in the experimental section. In Figure 6a-d, the values of the linear attenuation coefficient $(\mathrm{k})$ at different wavenumbers of 390 and $700 \mathrm{~nm}$ for all investigated EVA/PO films, with and without additives, before and after UBV exposure are reported. We chose to calculate the values of the linear attenuation coefficient at 390 and $700 \mathrm{~nm}$ because these variations can be related to film transparency. It is worth noting that the values of linear attenuation coefficients at $390 \mathrm{~nm}$ for $\mathrm{EVA} / \mathrm{PO}+\mathrm{CA}+\mathrm{STAB}$ films before exposure were higher than the values of EVA/PO blends and EVA/PO/CA (see Figure 6a). The same trends can 
also be noticed after $400 \mathrm{~h}$ of exposure time (see Figure $6 \mathrm{~b}$ ), and the latter can be attributed to the presence of stabilizers that are able to absorb UV irradiation. In the visible range, i.e., at $700 \mathrm{~nm}$, the values of the linear attenuation coefficients for the EVA/PO+CA+STAB blends are lower than those for the EVA/PO and EVA/PO+CA films, again highlighting the beneficial effect of the stabilizing systems used. However, all obtained data from UV-visible analysis suggest that $\mathrm{EVA} / \mathrm{PO}=75 / 25 \mathrm{wt} / \mathrm{wt} \%$, containing $\mathrm{CA}$ and STAB, shows transparency similar to that of neat $\mathrm{EVA}+\mathrm{CA}+\mathrm{STAB}$, making this blend a good candidate as an encapsulant material for bifacial PV modules.

\section{Conclusions}

EVA/PO blend films, with and without crosslinking agent (CA) and stabilizing systems (STAB), were formulated through melt mixing and then subjected to compression moulding at high temperature and under pressure, simulating a thermal treatment similar to that experienced by encapsulant films during PV module laminations and assembly.

All obtained results highlight that the addition of CA and STAB to the EVA/PO blend slightly increased the rigidity of the EVA-rich blend, and no beneficial effect on the rigidity of the PO-rich blend was noticed. Due to the presence of CA and STAB, the breakage properties of all EVA/PO blends slightly decreased; however, these decreases were less than 10\%, and the EVA-rich film can be considered a good candidate for PV encapsulants.

The thermal resistance at high temperature of EVA/PO blends, i.e., between $300{ }^{\circ} \mathrm{C}$ and 400 ${ }^{\circ} \mathrm{C}$, increased with increasing PO content. The EVA-rich blend containing CA and STAB showed increased thermal resistance in comparison to neat EVA containing CA and STAB, highlighting a beneficial effect due to the presence of PO at low amounts.

Concerning the photoaging behaviour, it is worth noting that crosslinking had no influence on the photostability of EVA but had a slight pro-degrading effect in the case of blends with polyethylene. All the results indicate that the stabilizer systems can protect the various blends but are much more efficient in the case of polyethylene than in the case of EVA.

Overall, the PV encapsulants must have properties that are a compromise between good mechanical behaviour before exposure, thermal resistance at high temperature (considering that the PV modules are subjected to an occasional hot-spot temperature increase), transparency and photoaging resistance in service, and considering all obtained results, an EVA-rich blend could be considered a good candidate for PV encapsulants, although its photoaging behaviour is slightly worse than that of neat EVA. 
Acknowledgements: M.B. thanks the Italian Ministry of University and Research (MUR) for financial support in the field of PON 2017 (cod. DOT1320558). 


\section{References}

[1] Ch. Farrell, A.I. Osman, X. Zhang, A. Murphy, R. Doherty, K. Morgan, D.W. Rooney, J. Harrison, R. Coulter, D, Shen, “Assessment of the energy recovery potential of waste photovoltaic (PV) modules " Scientific Reports 9 (2019) 5267, doi: 10.1038/s41598-019-41762-5.

[2] G. Cattaneo, J. Levra, H. Li, V. Barth, L. Sicot, A. Richter, C. Colletti, F. Rametta, M. Izzi, M. Despeisse, Ch. Ballif, "Encapsulant materials for high reliable bifacial heterojunction glass/glass photovoltaic module” 47th IEEE Photovoltaic Specialists Conference (PVSC), (2020) 1056-1061, doi: 10.1109/PVSC45281.2020.9300702.

[3] J. Pern, "Module encapsulation materials, processing and testing" APP International PV Reliability Workshop, 2008

[4] M. Kempe, "Evaluation of encapsulant materials for $P V$ application" Photovoltaic International, 9 (2010) 1049592, DOE: AC36-08GO28308

[5] J. Gaume, Ch. Taviot-Gueho, St. Cros, A. Rivaton, S. Therias, J-L. Gardette, "Optimization of PVA Clay Nanocomposite for Ultra-Barrier Multilayer Encapsulation of organic solar cells” Solar Energy Materials and Solar Cells 99 (2012) 240-249, DOI: 10.1016/j.solmat.2011.12.005.

[6] E.F. Cuddihy, C. Coulbert, A. Gupla, R. Liang, "Flat-Plate solar array project - Final report, Vol. VII: Module encapsulation” JPL publication 86-31 (1986), DOEIJPL-1012-12.

[7] W.F. Carroll, P. Schissel "Polymers in solar energy: Applications and opportunities" ACS Symposium Series, (1983). PII: 0097-6156/83/0220-0003\$06.00/0.

[8] F. J. Pern, “Ethylene-Vinyl Acetate (EVA) Encapsulants for photovoltaic modules: degradation and discoloration mechanisms and formulation modifications for improved photostability" Die Angewandte Makromolekulare Chemie 252 (1997) 195-216, DOI: 10.1002/apmc.1997.052520114. [9] M. Kempe "Overview of scientific issues involved in selection of polymers for pv applications" 37th IEEE Photovoltaic Specialists Conference (2011), DOI: 10.1109 / PVSC.2011.6185851.

[10] J.H. Wohlgemuth, T. Silverman, D.C. Miller, P. McNutt, M.D. Kempe and M. Deceglie, "Evaluation of PV module field performance", 42nd IEEE Photovoltaic Specialist Conference (2015), DOI: 10.1109/PVSC.2015.7356132.

[11] N.G. Dhere, M.B. Pandit, "Study of delamination in acceleration tested pv modules", 17th European Photovoltaic Solar Energy Conference (2001) 572- 575, Publ. Number: FSEC-PF-426-01. [12] G.J. Jorgensen, T.J. McMahon, “Accelerated and outdoor aging effects on photovoltaic module interfacial adhesion properties”, Progress in Photovoltaics: Research and Applications 16 (2008) 519-527, DOI: 10.1002/pip.826. 
[13] D.R. Coulter, E.F. Cuddihy, E.P. Pluedmann, “Chemical bonding technology for terrestrial photovoltaic modules" (1983) 1-65, DOE: JPL-1012-91.

[14] J.L. Koenig, F.J. Boerio, E.P. Plueddemann, J. Miller, P.B. Willis, E.F. Cuddihy, “Chemical bonding technology: direct investigation of interfacial bonds" (1986) 1-58, DOE: JPL-1012-120.

[15] V. Chapuis, S. Pelisset, M. Raeis-Barneoud, H.-Y. Li, C. Ballif, L.-E. Perret-Aebi, "Compressive-shear adhesion characterization of PVB and EVA at different curing times before and after exposure to damp-heat conditions", Progress in Photovoltaics: Research and Applications 22 (2014) 405-414, DOI: 10.1002/pip.2270.

[16] T.J. McMahon, G.J. Jorgensen, “Adhesion and thin-film module reliability”, 4th IEEE World Conference on Photovoltaic Energy Conference (2006) 2062-2065, DOI:10.1109/WCPEC.2006.279908.

[17] D.C. Miller, E. Annigoni, A. Ballion, J.G. Bokria, L.S. Bruckman, D.M. Burns, X. Chen, J. Feng, R.H. French, S. Fowler, Ch.C. Honeker, M.D. Kempe, H. Khonkar, M. Köhl, L.-E. PerretAebi, N.H. Phillips, K.P. Scott, F. Sculati-Meillaud, J.H. Wohlgemuth, "Degradation in PV encapsulant strength of attachment: An interlaboratory study towards a climate-specific test” IEEE 43rd Photovoltaic Specialists Conference (2016), DOI: 10.1109 / PVSC.2016.7749556.

[18] T. Burns and M. D. White and J. Naumovitz and K. Nanjundiah, "Improved performance encapsulation film based on polyolefin" Materials Science (2012), DOI: 10.4229/27THEUPVSEC2012-4BV.2.47.

[19] M.D. Kempe, G.J. Jorgensen, K.M. Terwilliger, T.J. McMahon, Ch.E. Kennedy, T.T. Borek, "Acetic acid production and glass transition concerns with ethylene-vinyl acetate used in photovoltaic devices" Solar Energy Materials and Solar Cells 91, 4 (2007) 315-329, DOI: 10.1016/j.solmat.2006.10.009.

[20] L.-E. Perret-Aebi, H.-Y. Li, R. Théron, G. Roeder, Y. Luo, T. Turlings, R. F. M. Lange, C. Ballif "Insights on EVA lamination process: Where do the bubbles come from?" 25th European Photovoltaic Solar Energy Conference and Exhibition (2010) 4036-4038, DOI: 10.4229/25thEUPVSEC2010-4AV.3.24.

[21] N.C. Park, J.S. Jeong, B.J. Kang, D.H. Kim "The effect of encapsulant discoloration and delamination on the electrical characteristics of photovoltaic module” Microelectronics Reliability 53 (2013) 1818-1822, DOI: 10.1016/j.microrel.2013.07.062.

[22] A. Virtuani, L. Manni, David Pic, Jean-Louis Allary, Edgardo Saucedo "A comprehensive protocol for assessing the quality of the lamination process of thin film glass/glass modules" 31 th European Photovoltaic Solar Energy Conference and Exhibition (2015) 2444-2448, DOI: 10.4229/EUPVSEC20152015-5BV.4.19. 
[23] M.C. López-Escalante, L.J. Caballero, F. Martín, M. Gabás, A. Cuevas, J.R. Ramos-Barrado "Polyolefin as PID-resistant encapsulant material in PV modules" Solar Energy Materials and Solar Cells, 144 (2016) 691-699, DOI: 10.1016/j.solmat.2015.10.009.

[24] B. Adothu, P. Bhatt, S. Zele, J. Oderkerk, F.R. Costa, S. Mallick, “Investigation of newly developed thermoplastic polyolefin encapsulant principle properties for the c-Si PV module application" Materials Chemistry and Physics 243 (2020) 122660, DOI: 10.1016/j.matchemphys.2020.122660.

[25] G. Cattaneo, F. Galliano, V. Chapuis, H.-Y. Li, Ch. Schlumpf, A. Faes, Th. Söderström, Y. Yao, R. Grischke, M. Gragert, Ch. Ballif, L.-E. Perret-Aebi, “Encapsulants characterization for novel photovoltaic module design" 29th European Photovoltaic Solar Energy Conference and Exhibition (2014) 147-151, DOI: 10.4229/EUPVSEC20142014-1BV.6.36.

[26] M.C. Carvalho de Oliveira, A.S.A.C. Diniz, M.M. Viana, V. de Freitas Cunha Lins, “The causes and effects of degradation of encapsulant ethylene vinyl acetate copolymer (EVA) in crystalline silicon photovoltaic modules: A review” Renewable and Sustainable Energy Reviews 81 (2018) 2299-2317, DOI: 10.1016/j.rser.2017.06.039.

[27] M. Rodriguez-Vazquez, Ch.M. Liauw, N.S. Allen, M. Edge, E. Fontan, "Degradation and stabilisation of poly(ethylene-stat-vinyl acetate): Spectroscopic and rheological examination of thermal and thermo-oxidative degradation mechanisms" Polymer Degradation and Stability 91 (2006) 154-164, DOI: 10.1016/j.polymdegradstab.2005.04.034.

[28] J. Jin, Sh. Chen, J. Zhang, "UV aging behavior of ethylene-vinyl acetate copolymers (EVA) with different vinyl acetate contents" Polymer Degradation and Stability 95 (2010) 725-732, DOI: 10.1016/j.polymdegradstab.2010.02.020.

[29] NS. Allen, M. Edge (Eds.), "Fundamental of polymer degradation and stabilization of polyolefins” Elsevier: Applied Science, Essex, UK (1992).

[30] S. Morlat-Therias, E. Fanton, J.-L. Gardette, S. Peeterbroeck, M. Alexandre, Ph. Dubois, "Polymer/carbon nanotube nanocomposites: Influence of carbon nanotubes on EVA photodegradation" Polymer Degradation and Stability 92 (2007) 1873-1882, DOI: 10.1016/j.polymdegradstab.2007.06.021.

[31] X.-M. Shi, J. Zhang, D.-R. Li, Sh.-J. Chen, "Effect of damp-heat aging on the structures and properties of ethylene-vinyl acetate copolymers with different vinyl acetate contents" Journal of Applied Polymer Science 112 (2009) 2358-2365, DOI: 10.1002/app.29659.

[32] Sh. Chen, J. Zhang, J. Su, "Effect of hot air aging on the properties of ethylene vinyl acetate copolymer and ethylene-acrylic acid copolymer blends" Journal of Applied Polymer Science, 112 (2009) 1166-1174, DOI: 10.1002/app.29506. 
[33] J.C. Schlothauer, C. Peter, Ch. Hirschl, G. Oreski, B. Röder, "Non-destructive monitoring of ethylene vinyl acetate crosslinking in PV-modules by luminescence spectroscopy” Journal of Polymer Research 24, (2017) 233, DOI: 10.1007/s10965-017-1409-y.

[34] J.C. Schlothauer, K. Grabmayer, I. Hintersteiner, G.M. Wallner, B. Röder, "Non-destructive 2d-luminescence detection of EVA in aged PV modules: correlation to calorimetric properties, additive distribution and a clue to aging parameters" Solar Energy Materials \& Solar Cells 159 (2017) 307-317, DOI: 10.1016/j.solmat.2016.09.011.

[35] X. Gu, Y. Pang, Ch.-C. Lin, K. Liu, T. Nguyen, J.W. Chin, “Linking accelerated laboratory and outdoor exposure results for PV polymeric materials - a mechanistic study of EVA", Reliability of Photovoltaic Cells, Modules, Components, and Systems VI, 8825 (2013) 88250L, DOI: 10.1117/12.2024532.

[36] F.P. La Mantia, V. Malatesta, M. Ceraulo, M.C. Mistretta, P. Koci "Photooxidation and photostabilization of EVA and cross-linked EVA" Polymer Testing, 51 (2016) 6-12, DOI: 10.1016/j.polymertesting.2016.01.018.

[37] A.W. Czanderna, F.J. Pern, "Encapsulation of PV modules using ethylene vinyl acetate copolymer as a pottant: A critical review” Solar Energy Materials and Solar Cells 43 (1996) 101181, DOI: 10.1016/0927-0248(95)00150-6.

[38] F.J. Pern, "Factors that affect the EVA encapsulant discoloration rate upon accelerated exposure”, Solar Energy Materials and Solar Cells, 41/42 (1996) 587-615, DOI: 10.1016/09270248(95)00128-X

[39] F.J. Pern, S.H. Glick, "Thermal processing of EVA encapsulants and effects of formulation additives", Conference Record of $25^{\text {th }}$ IEEE Photo- voltaic Specialists Conference (1996)12511254, DOI: 10.1109 / PVSC.1996.564359.

[40] F.J. Pern, "EVA encapsulants for photovoltaic modules: degradation and discoloration mechanisms and formulation modifications for improved photostability", Die Angewandte Makromolekulare Chemie 252 (1997) 195 - 216 (4523), DOI: 10.1002/apmc.1997.052520114.

[41] Sh. Deng, Zh. Zhang, Ch. Ju, J. Dong, Zh. Xia, X. Yan, T. Xu, G. Xing, "Research on hot spot risk for high-efficiency solar module" Energy Procedia, 130 (2017) 77-86, DOI: 10.1016/j.egypro.2017.09.399.

[42] H.J. Solheim, H.G. Faer, E.A. Sorheim, S.E. Foss, "Measurement and simulation of hot spots in solar cells” Energy Procedia 38 (2013) 183-189, DOI: 10.1016/j.egypro.2013.07.266.

[43] M. Simon, E.L. Meyer, "Detection and analysis of hot-spot formation in solar cells" Solar Energy Materials and Solar Cells 94 (2010) 106-113, DOI: 10.1016/j.solmat.2009.09.016. 
[44] J.L. Philippart, C. Sinturel, J.-L. Gardette, "Influence of light intensity on the photooxidation of polypropylene" Polymer Degradation and Stability 58 (1997) 261-268, DOI: 10.1016/S01413910(97)00056-6.

[45] M. Gardette, A. Perthue, J.L.Gardette, T. Janecska, E. Földes, B. Pukánszky, S. Therias. "Photo- and thermal-oxidation of polyethylene: comparison of mechanisms and influence of unsaturation content" Polymer Degradation and Stability 98 (2013) 2383-2390, DOI: 10.1016/j.polymdegradstab.2013.07.017.

[46] M.C.C. Oliveira, A.S.A.C. Diniz, M.M. Viana, VFC Lins, "The causes and effects of degradation of encapsulant ethylene vinyl acetate copolymer (EVA) in crystalline silicon photovoltaic modules: A review” Renewable and Sustainable Energy Reviews 81 (2018) 22992317, DOI: 10.1016/j.rser.2017.06.039.

[47] J. Jin, Sh. Chen, J. Zhang, “UV aging behaviour of ethylene-vinyl acetate copolymers (EVA) with different vinyl acetate contents" Polymer Degradation and Stability 95 (2010) 725-732, DOI: 10.1016/j.polymdegradstab.2010.02.020.

[48] J.L. Gardette, A. Rivaton, S. Therias, "Photodegradation processes in polymeric materials" in n.s. allen (ed.), "photochemistry and photophysics of polymer materials", John Wiley \& Sons, Inc. Hoboken, New Jerse, USA (2010) 569-601, DOI:10.1002/9780470594179.

[49] S. Therias, N.Tz. Dintcheva, J.L. Gardette, F.P. La Mantia, ”Photooxidative behaviour of polyethylene/polyamide-6 blends" Polymer Degradation and Stability 95 (2010) 522-526, DOI: 10.1016/j.polymdegradstab.2009.12.017. 


\section{Figure captions}

Figure 1. Mechanical properties: (a) elastic modulus, E, (b) tensile strength, TS, and (c) elongation at break, $\mathrm{EB}$, of different $\mathrm{EVA} / \mathrm{PO}, \mathrm{EVA} / \mathrm{PO}+\mathrm{CA}$ and $\mathrm{EVA} / \mathrm{PO}+\mathrm{CA}+\mathrm{STAB}$

Figure 2. TGA curves of EVA/PO blends containing crosslinking agent (CA) and stabilizers (STAB)

Figure 3. FTIR spectra of films (94 microns) of (a) EVA/PO 100/0, (b) EVA/PO 0/100 $+\mathrm{CA}+\mathrm{STAB}$ and (c) EVA/PO 50/50, (d) EVA/PO 50/50 +CA and (e) EVA/PO 50/50 +CA+STAB before $(0 \mathrm{~h})$ and after UVB exposure (400 h)

Figure 4. Variation of absorbance at $1780 \mathrm{~cm}^{-1}$ of EVA/PO, EVA/PO/CA and EVA/PO/CA/STAB with various amounts of EVA and PO after: (4a) $200 \mathrm{~h}$ and (4b) $400 \mathrm{hs}$ exposure SEPAP 12.24/52 ${ }^{\circ} \mathrm{C}$

Figure 5. UV-visible spectra of EVA/PO, EVA/PO+CA and EVA/PO+CA+STAB before $(0 \mathrm{~h})$ and after UVB exposure (400 h)

Figure 6. Linear attenuation coefficient, $K$, of EVA/PO, EVA/PO+CA and EVA/PO+CA+STAB under different conditions: (a) $0 \mathrm{~h}$, at $390 \mathrm{~nm}$, (b) $400 \mathrm{~h}$, at $390 \mathrm{~nm}$, (c) $0 \mathrm{~h}$, at $700 \mathrm{~nm}$, (d) $400 \mathrm{~h}$, at $700 \mathrm{~nm}$. 

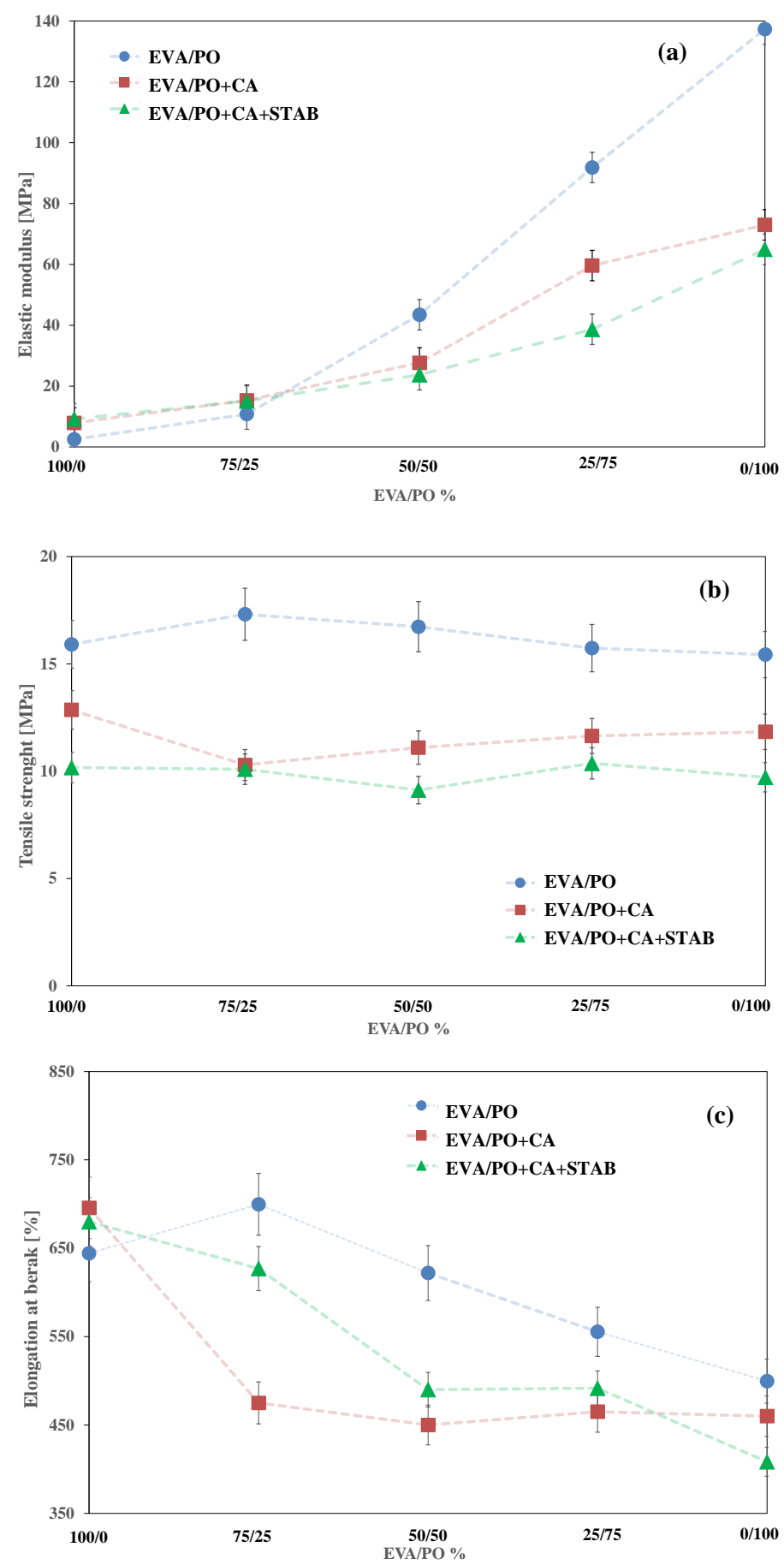

Figure 1. Mechanical properties: (a) elastic modulus, E, (b) tensile strength, TS, and (c) elongation at break, EB, of different EVA/PO, EVA/PO+CA and EVA/PO+CA+STAB 


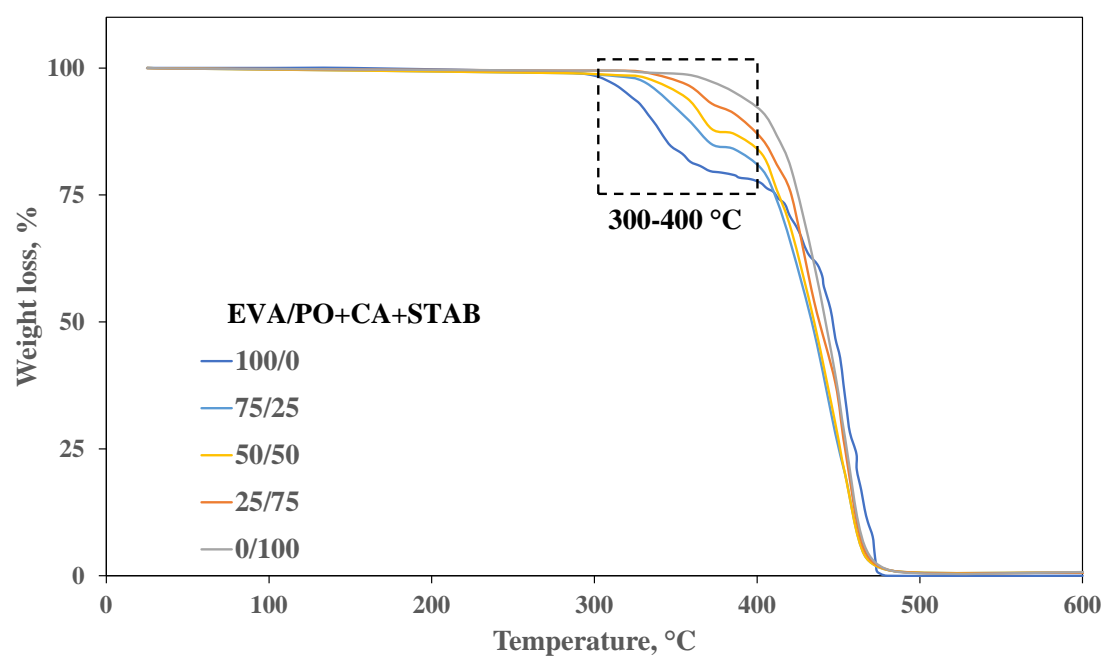

Figure 2. TGA curves of EVA/PO blends containing crosslinking agent (CA) and stabilizers (STAB) 


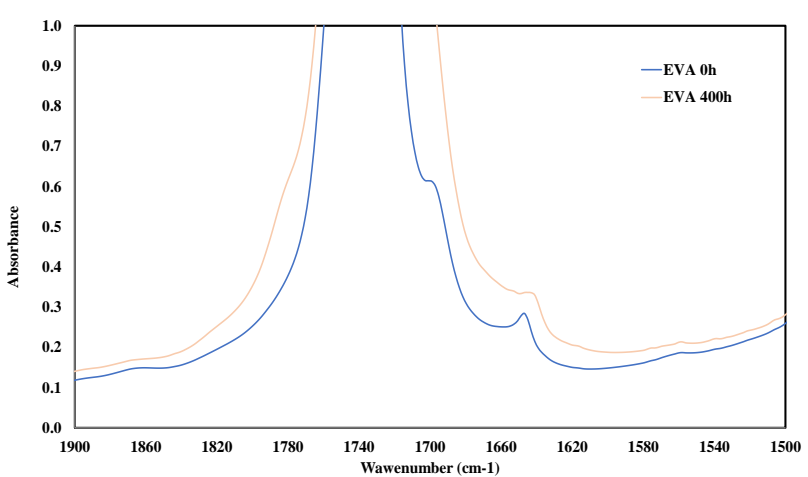

(a) EVA/PO 100/0

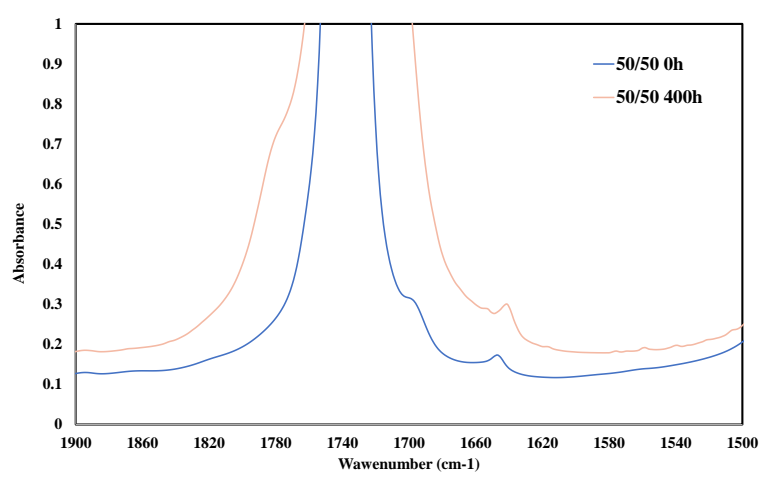

(c) EVA/PO 50/50

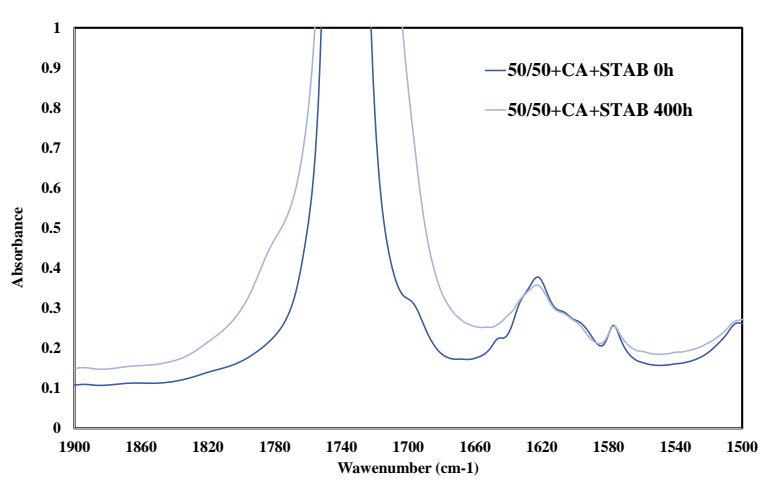

(e) EVA/PO 50/50 + CA+STAB

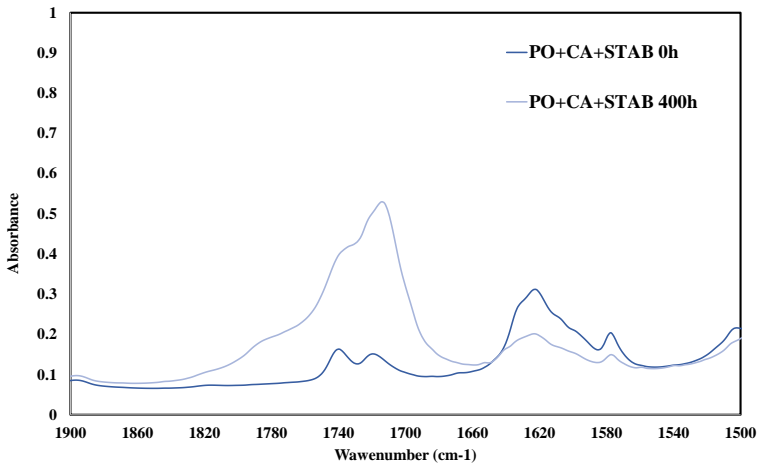

(b) EVA/PO 0/100 + CA+STAB

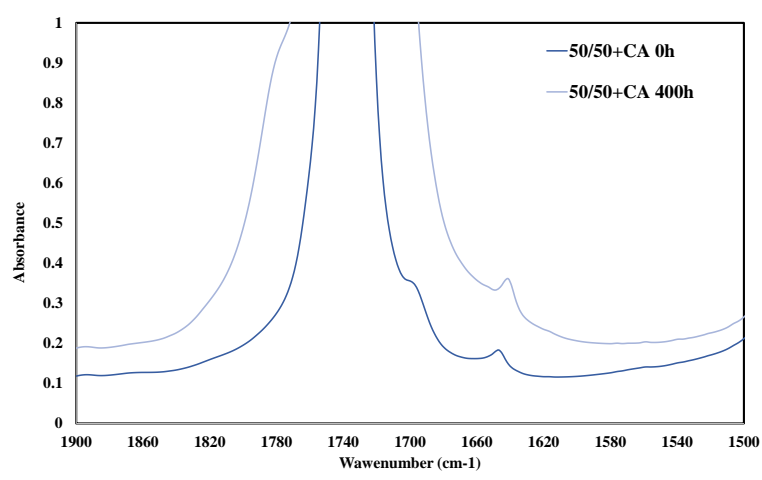

(d) EVA/PO 50/50 + CA

Figure 3. FTIR spectra of films (94 microns) of (a) EVA/PO 100/0, (b) EVA/PO 0/100 $+\mathrm{CA}+\mathrm{STAB}$ and (c) EVA/PO 50/50, (d) EVA/PO 50/50 +CA and (e) EVA/PO 50/50 +CA+STAB before $(0 \mathrm{~h})$ and after UVB exposure $(400 \mathrm{~h})$ 

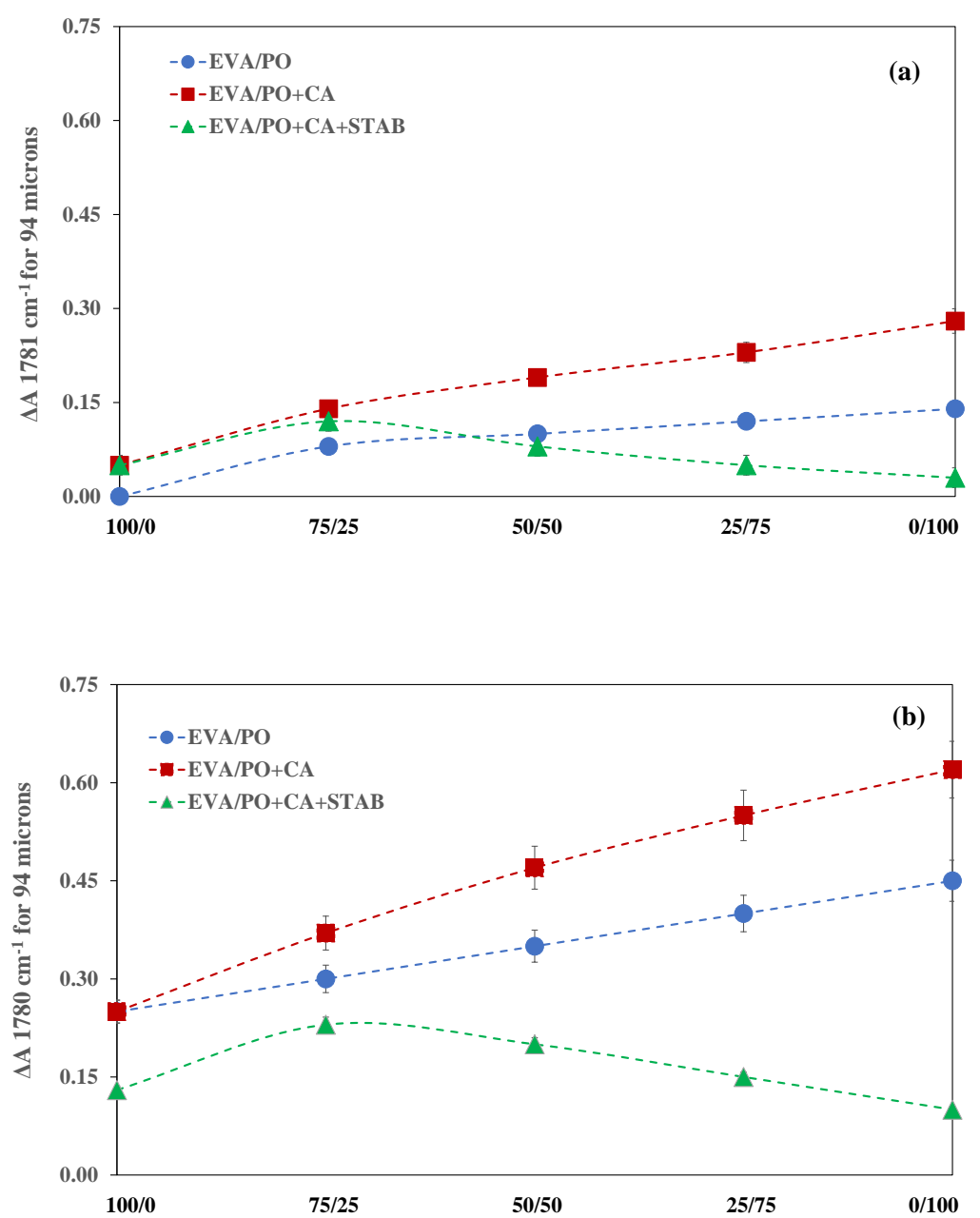

Figure 4. Variation in absorbance $(\triangle \mathrm{A})$ at $1780 \mathrm{~cm}^{-1}$ of EVA/PO, EVA/PO+CA and EVA/PO+CA+STAB after (a) $200 \mathrm{~h}$ and (b) $400 \mathrm{~h}$ of exposure to SEPAP $12.24 / 52{ }^{\circ} \mathrm{C}$ 

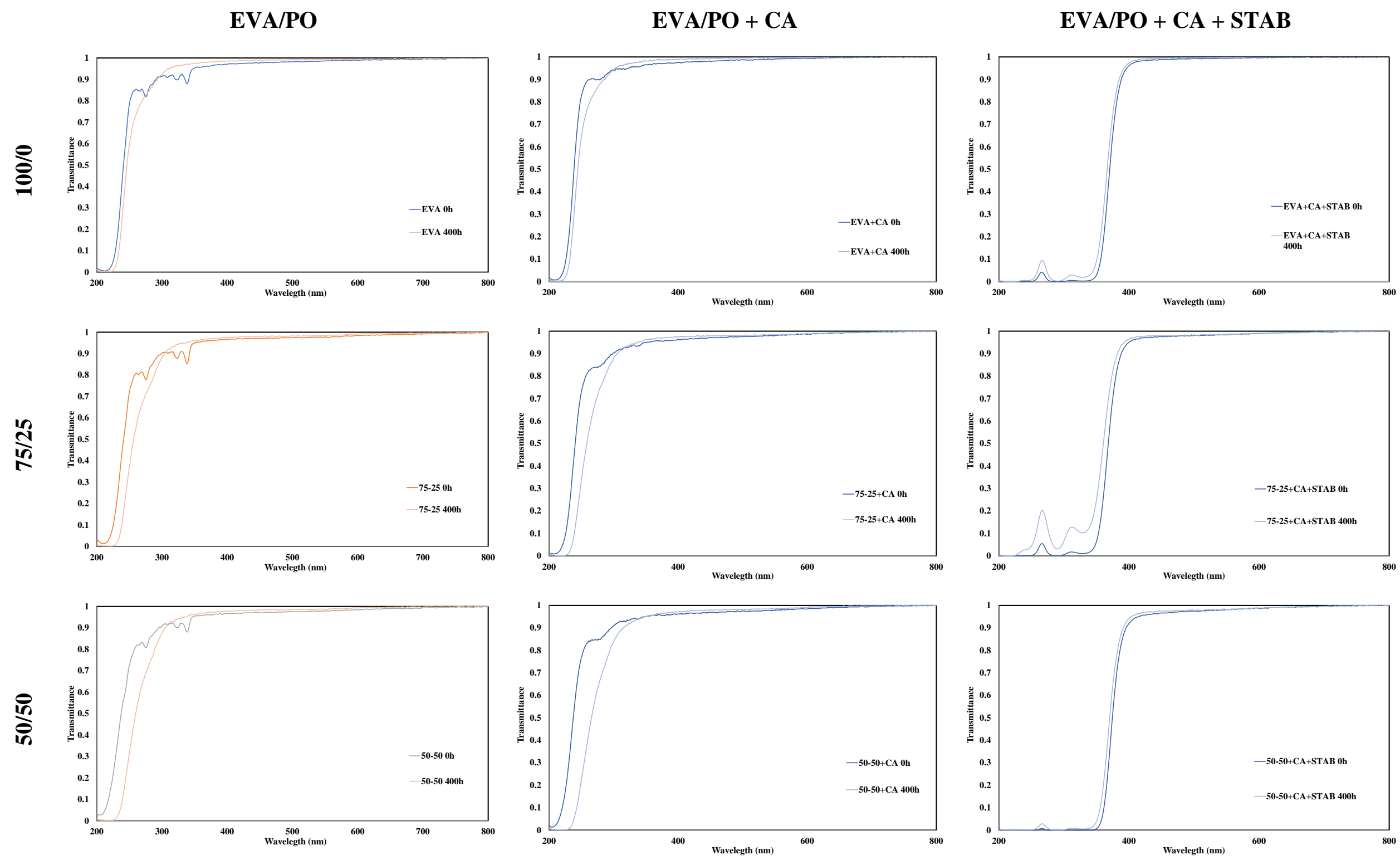

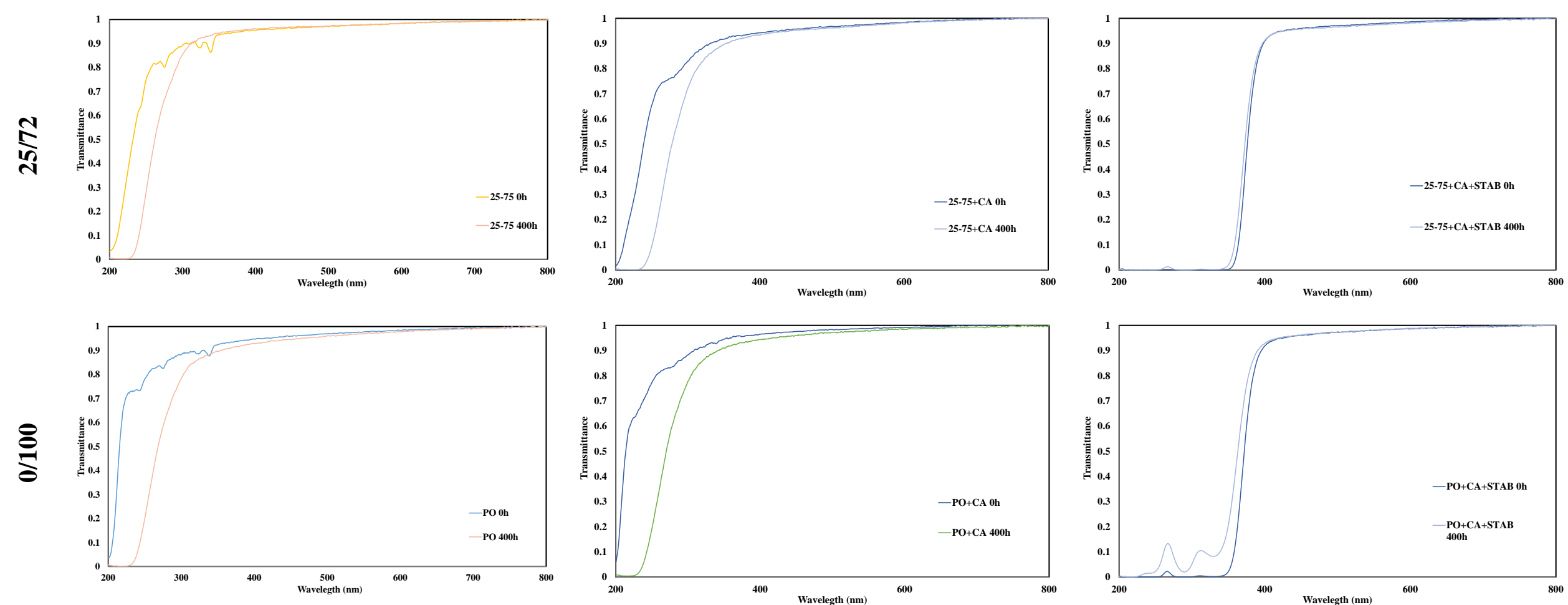

Figure 5. UV-visible spectra of EVA/PO, EVA/PO+CA and EVA/PO+CA+STAB before $(0 \mathrm{~h})$ and after UVB exposure (400 h) 
Before exposure $(\mathbf{0}$ h)
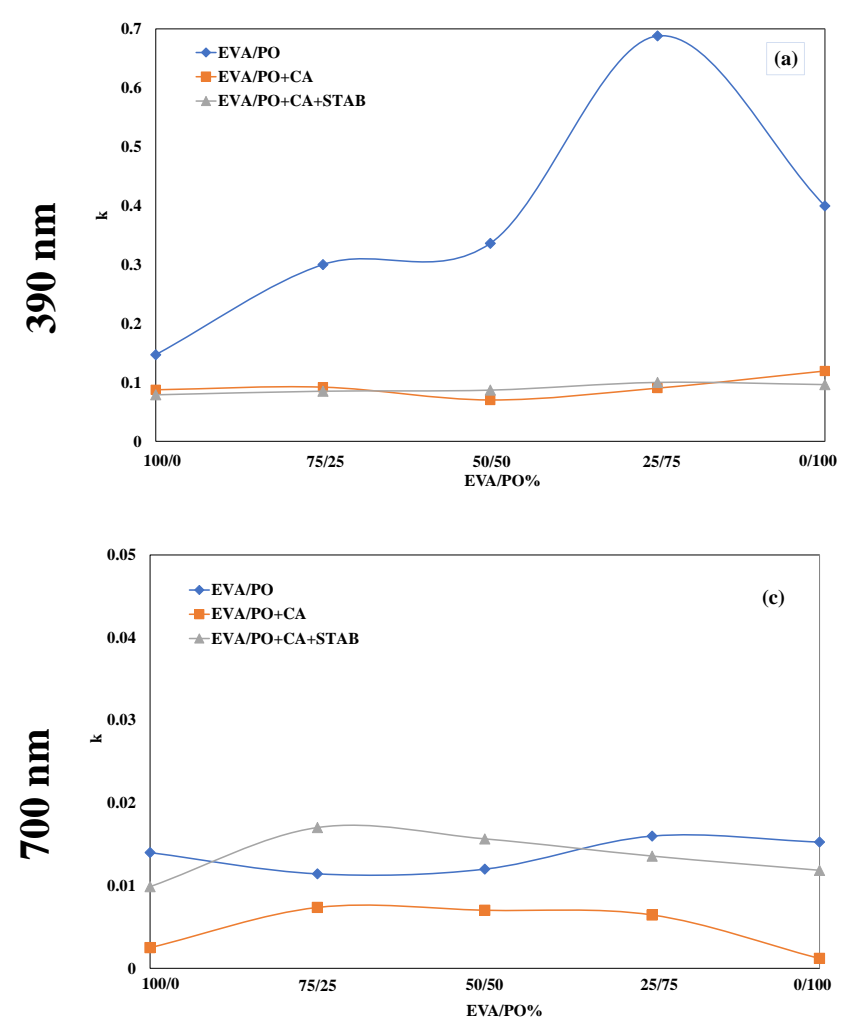

After UVB exposure (400 h)
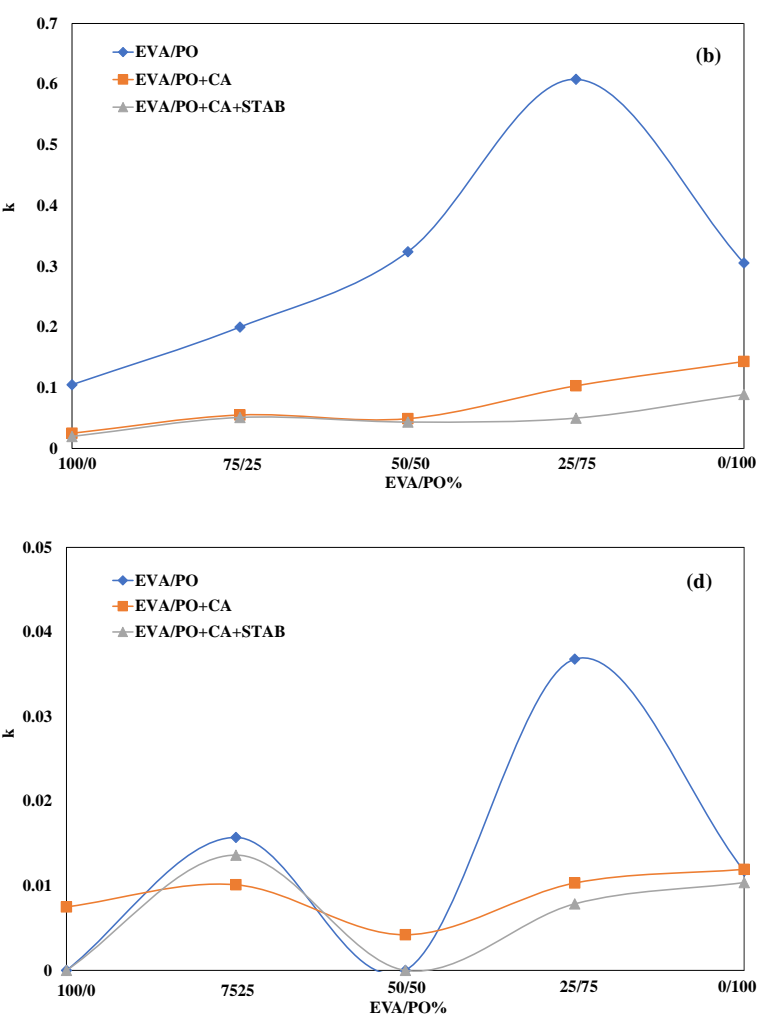

Figure 6. Linear attenuation coefficient, $K$, of EVA/PO, EVA/PO+CA and EVA/PO+CA+STAB under different conditions: (a) $0 \mathrm{~h}$, at $390 \mathrm{~nm}$, (b) $400 \mathrm{~h}$, at $390 \mathrm{~nm}$, (c) $0 \mathrm{~h}$, at $700 \mathrm{~nm}$, (d) $400 \mathrm{~h}$, at $700 \mathrm{~nm}$. 